(RESEARCH ARTICLE)

\title{
Antibacterial potential of plant extracts on ESBL and carbapenemase producing pathogens
}

Patade Swamini Vasant, Philip Vivian Victor, Amin Hussain Murtuza, Mukherjee Debarshi, Khan Afzal Naushad, Nair Swathi Sajith, George Jerry, Pandey Ankita Shivshankar, Mundra Pooja Suresh and K Aruna *

Department of Microbiology, Wilson College, Mumbai 400007, Maharashtra, India.

Publication history: Received on 21 March 2020; revised on 25 March 2020; accepted on 28 March 2020

Article DOI: https://doi.org/10.30574/gscbps.2020.10.3.0073

\begin{abstract}
The extensive spread of antibiotic resistance among pathogens is critically challenging the healthcare system with treatment options. Often, the physicians are left with no choice but to use high doses of antibiotics to combat infectious diseases in spite of the associated toxicity. In an attempt to investigate plant sources as an alternative source of drugs, the current study evaluated the antibacterial activity of extracts obtained from six commonly available plants against 16 pathogens isolated from skin, respiratory and urinary tract. Among these, 14 multi drug resistant pathogens and 7 ESBL producers were identified. Also, 4 isolates showed both ESBL and carbapenemase production whereas 2 S. aureus isolates showed ESBL production and resistance to Streptogramins. The plants used in our study included garlic, cinnamon, Indian borage, clove, green tea and onion. The qualitative analysis of antibacterial activity was carried out by well diffusion method for water and methanol extracts of these plants. The results indicated garlic and Indian borage water extracts to be active against both gram negative and gram positive test pathogens. The observed zones of inhibition were in the range of 11-27 mm (Indian borage) and 9-21 mm (garlic) against the test pathogens. However, no synergy was observed when these extracts were combined.
\end{abstract}

Keywords: $\beta$-lactamase; Alternative remedy; Antibacterial activity; Antibiotic resistance

\section{Introduction}

The successful identification of novel antibiotics and, its increased production and administration, in the last three decades has simultaneously eventuated the emergence of antibiotic resistant pathogens [1]. Over time, the resistance genes have been transmitted through horizontal gene transfer to aid in an increased occurrence of infections caused by drug resistant pathogens. Moreover, the accumulation of multiple resistance genes in a single pathogen has allowed the evolution of Multiple Drug Resistant (MDR) pathogens and superbugs [2].

Among the resistance observed towards several classes of antibiotics, the pathogens showing resistance to $\beta$-lactam group of antibiotics are particularly frightening. This is because, the $\beta$-lactams are broad spectrum antibiotics widely used for treatment of commonly occurring infectious diseases [3]. The spread of Extended-Spectrum $\beta$-Lactamase (ESBL) and carbapenemase (i.e., types of $\beta$-lactamases) producing pathogens are reported to occur at an alarming rate, with over $50 \%$ drug resistant pathogens identified as ESBL producers in recent years [4]. The ESBLs generally confers resistance to cephalosporins e.g. cefuroxime, cefotaxime and ceftazidime, while the carbapenemases characteristically hydrolyze carbapenem antibiotics like imipenem, ertapenem and meropenem. In addition, they also show a high degree of resistance to most $\beta$-lactams and other groups of antibiotics $[5,6,7]$.

\footnotetext{
* Corresponding author: K Aruna
} 
The contemplating action for the observed scenario demands our sincere focus towards the use of alternative remedies in combating antimicrobial resistance. Verily, many published studies report the potential of plant extracts as a possible alternative to antibiotics $[8,9,10]$. However, comparatively few documented records including research publications report the efficiency of plant extracts in treatment of infections caused by multi drug resistant pathogens [11, 12].

The plant derived medicines are the pre-eminent choice of pharmaceutical experts as a result of the indelible role of plants in the prevention and treatment of human diseases since a long time [13]. Moreover, it is estimated that around 61\% of new drugs developed between 1981 and 2002 were derived from plant products [14]. These drugs are successfully applied in treatment of infectious diseases caused by bacteria, viruses, helminths and protozoa, as well as chronic diseases like cancer, HIV, diabetes and hypertension [15]. Furthermore, the traditional Ayurveda and chinese medicine, that exploits herbal sources of drugs, have a well-built foundation and effective curative potential in treatment of common as well as chronic diseases [16].

Among the various plants known for their antimicrobial potential, the current study narrowed down the list to six commonly available spices and plant products i.e., clove, garlic, cinnamon, onion, green tea and Indian borage, to investigate its potential against ESBL and carbapenemase producing pathogens specifically.

Spices not only provide flavour and aroma to the foods but are also rich in potent biomolecules. The secondary metabolites such as tannins, terpenoids, alkaloids, flavonoids, and glycosides, among others, majorly contribute to antimicrobial and anti-oxidant properties of plants [17]. Spices are rich sources of these compounds. Cloves are known for its carminative properties and works by increasing the concentration of hydrochloric acid in the stomach to improve peristalsis [18]. It is also widely used as anodyne in dentistry [19]. The sulphur compounds like allin contribute to the strong smell of garlic and it is the major bioactive compound with several medicinal properties [20]. The neuroprotective property of cinnamon is exploited in the management of diabetes in Chinese medicine [21]. Similarly, the tumour inhibitory property of flavonols and organosulfur compounds in onion has been reported [22]. The polyphenols acting as anti-oxidants are present in considerably higher amounts in green tea and its supplements [23]. The anti-mutagenic, antigenotoxic and antibacterial effects of Indian borage leaves are also well documented [24]. Altogether these plants products commonly show anti-inflammatory, antioxidants, antiulcerogenic, antithrombotic antiparasitic, antibacterial and anti-inflammatory activities [18-24]. In an attempt to investigate the efficacy of the extracts obtained from these plants and plant products against ESBL and carbapenemase producing pathogens, the current study was carried out to qualitatively check their antibacterial activity.

\section{Material and methods}

\subsection{Test organisms}

A total of 16 test pathogens causing skin, respiratory and urinary tract infections were collected from Saifee Hospital situated in South Mumbai. In addition, 3 representative laboratory cultures were also used. The details of test pathogens are provided in Table 1 below. All the isolates were maintained on Nutrient Agar (NA) slants supplemented with 100 $\mu \mathrm{g} / \mathrm{mL}$ of ampicillin and stored at refrigerated conditions.

\subsection{Antibiotic resistance profile and detection of $\beta$-lactamase production}

For carrying out the antibiotic resistance profile of test isolates, they were enriched in sterile nutrient broth for $6-8 \mathrm{~h}$ at $37^{\circ} \mathrm{C}$. The enriched culture was swabbed on the surface of sterile Mueller and Hinton agar plates and antibiotic discs were aseptically placed over them [25]. The plates were incubated at $37^{\circ} \mathrm{C}$ for $24 \mathrm{~h}$ and the diameters of the zone of inhibition were measured. All media used in the present study were obtained from Hi-media Laboratories Ltd., Mumbai, India.

The resistance of test isolates was tested against 33 antibiotics of different classes commonly used for the treatment of skin, respiratory and urinary tract infections. The antibiotics used in our study included Ticarcillin/Clavulanic acid (Tc $75 \mu \mathrm{g}$ ), Ceftazidime (Ca $30 \mu \mathrm{g}$ ), Cefoperazone/Sulbactam (Cs $50 \mu \mathrm{g}$ ), Meropenem (Mr $10 \mu \mathrm{g}$ ), Ciprofloxacin (Cf $5 \mu \mathrm{g}$ ), Levofloxacin (Le $5 \mu \mathrm{g}$ ), Minocycline (Mi $30 \mu \mathrm{g}$ ), Trimethoprim/Sulphamethoxazole (Tr $75 \mu \mathrm{g}$ ), Ampicillin (As $10 \mu \mathrm{g}$ ), Amoxycillin/Clavulanic acid (Ac $20 \mu \mathrm{g}$ ), Piperacillin/Tazobactam (Pt $100 \mu \mathrm{g}$ ), Cefuroxime (Cu $30 \mu \mathrm{g})$, Ceftriaxone (Ci 30 $\mu \mathrm{g}$ ), Cefipime (Cpm $30 \mu \mathrm{g}$ ), Ertapenem (Etp $10 \mu \mathrm{g}$ ), Imipenem (I $10 \mu \mathrm{g}$ ), Amikacin (Ak $30 \mu \mathrm{g})$, Gentamicin (G $10 \mu \mathrm{g}$ ), Nalidixic acid (Na $30 \mu \mathrm{g}$ ), Nitrofurantoin (Nf $300 \mu \mathrm{g}$ ), Colistin (Cl $10 \mu \mathrm{g}$ ), Aztreonam (Ao $30 \mu \mathrm{g}$ ), Benzyl penicillin (Ban $10 \mathrm{U}$ ), Erythromycin (E $15 \mu \mathrm{g}$ ), Linezolid (Lz $30 \mu \mathrm{g}$ ), Daptomycin (Dap $30 \mu \mathrm{g}$ ), Teicoplanin (Te $30 \mu \mathrm{g}$ ), Vancomycin (Va $30 \mu \mathrm{g}$ ), Tetracycline (T $30 \mu \mathrm{g}$ ), Oxacillin (Ox $1 \mu \mathrm{g}$ ), Clindamycin (Cd $2 \mu \mathrm{g}$ ), Rifampicin (R $5 \mu \mathrm{g}$ ) and Tigecycline (Ti $15 \mu \mathrm{g}$ ). 
In addition, the production of ESBL was detected with the help of Multi-Ezy MICTM strips (Hi-Media Laboratories Pvt. Ltd.), which contained a gradient of 3 antibiotics with and without clavulanic acid on either side of the strip. The MultiEzy MIC ${ }^{\mathrm{TM}}$ strips used in the study contained cefotaxime, ceftazidime, and cefepime (MIX) on one side in a two-fold gradient and the same antibiotics with clavulanic acid (MIX+) on the other side. Table 2 indicates the interpretation criteria for detection of ESBL producers [26]. Reference cultures used in the study were E. coli ATCC 25922; used as negative control, and K. pneumoniae ATCC 700603; used as positive control, for detection of ESBL production. The detection of carbapenemase production was reported based on the antibiotic sensitivity test, by observing for resistance to carbapenem antibiotics i.e. imipenem, meropenem and/or ertapenem.

Table 1 Test pathogens used in the current study

\begin{tabular}{lll}
\hline Reference code & Name of organism & Source \\
\hline M-01 & Escherichia coli & Urine \\
M-125 & Klebsiella pneumonia & Urine \\
M-150 & Burkholderia cepacia & Urine \\
M-160 & Enterococcus faecalis & Urine \\
M-04 & Escherichia coli & Urine \\
M-09 & Acinetobacter baumannii & Respiratory tract \\
M-40 & Enterobacter cloacae ssp. Dissolvens & Respiratory tract \\
M-126 & Pseudomonas aeruginosa & Respiratory tract \\
M-10 & Klebsiella pneumoniae & Respiratory tract \\
M-139 & Acinetobacter baumannii & Respiratory tract \\
M-14 & Escherichia coli & Skin \\
M-33 & Staphylococcus epidermidis & Skin \\
M-98 & Enterococcus faecium & Skin \\
M-132 & Staphylococcus aureus & Skin \\
M-141 & Pseudomonas aeruginosa & Skin \\
M-109 & Staphylococcus aureus & Skin \\
L-1 & Escherichia coli & Lab culture \\
L-2 & Staphylococcus aureus & Lab culture \\
L-3 & Staphylococcus aureus $6538 p$ & Lab culture \\
\hline
\end{tabular}

Table 2 Interpretation of E-Test

\begin{tabular}{|c|c|c|}
\hline Report & Formula & Interpretative Criteria \\
\hline $\begin{array}{l}\text { ESBL } \\
\text { strain }\end{array}$ & $\begin{array}{l}\mathrm{MIX}=\geq 8 \\
\mathrm{MIX}+\end{array}$ & $\begin{array}{l}\text { When the ratio obtained for MIX and MIX+ is more than or equal } \\
\text { to } 8 \\
\text { or in the case when, no zone is obtained for MIX and a zone is } \\
\text { obtained for MIX+ }\end{array}$ \\
\hline $\begin{array}{l}\text { ESBL } \\
\text { strain }\end{array}$ & $\begin{array}{l}\mathrm{MIX}=\leq 8 \\
\mathrm{MIX}+\end{array}$ & $\begin{array}{l}\text { When the ratio of the value obtained for MIX in combination with } \\
\text { MIX+ is less than } 8 .\end{array}$ \\
\hline $\begin{array}{l}\text { ESBL } \\
\text { conclusive) }\end{array}$ (non- & & $\begin{array}{l}\text { When no zone of inhibition is obtained on either side. In such } \\
\text { cases, resistance may be due to mechanisms other than ESBL } \\
\text { production. These have to be further investigated before } \\
\text { reporting. }\end{array}$ \\
\hline
\end{tabular}

\subsection{Plant sample collection}

The buds of clove (Syzygium aromaticum), bulb of garlic (Allium sativum), bark of cinnamon (Cinnamomum zelanicum), onion (Allium cepa) and green tea (Camellia sinensis) were purchased from a local supermarket in Mumbai. The leaves 
of Indian borage (Plectranthus amboinicus) was collected from a local garden and authenticated by an expert botanist from St. Xaviers College, Mumbai.

\subsection{Preparation of extracts}

In our study, the plant extracts were prepared using water and methanol. For the preparation of water extract, different weight of plant material was crushed using mortar and pestle and added to $100 \mathrm{~mL}$ distilled water. They were covered with aluminium foil to avoid volatilization and kept in shaker incubator maintained at $42^{\circ} \mathrm{C}$ for $48 \mathrm{~h}$. Different concentrations of plant material $(5-50 \mathrm{mg} / \mathrm{mL})$ were used in our study to check for qualitative antibacterial activity and the concentration showing maximum activity was used for further experiment. The methanol extract was prepared similarly using a soxhlet apparatus. The bioactive components from plants were extracted at $65^{\circ} \mathrm{C}$ for $20 \mathrm{~h}$. The obtained extract was covered with aluminium foil to avoid volatilization and kept in a rotary shaker at $42^{\circ} \mathrm{C}$ for $48 \mathrm{~h}$. The dried extracts were further diluted using DMSO to obtain a final desired concentration.

\subsection{Qualitative evaluation of antibacterial activity of plant extracts by agar diffusion method}

The antibacterial activity of plant extracts against test pathogens was assayed by agar well diffusion method. For this purpose, $20 \mathrm{~mL}$ of sterile and molten NA butt was cooled to around $40^{\circ} \mathrm{C}$, seeded with $0.2 \mathrm{~mL}$ of test cultures $(0.12$ $0 . D 540 \mathrm{~nm}$ ) and $0.2 \mathrm{~mL}$ Triphenyl tetrazolium chloride (TTC). The mixture was then poured into sterile petri plates. Using a sterile cork borer wells were punched in each plate after solidification of the medium and $50 \mu \mathrm{L}$ of the extract was added to the wells. The plates were incubated at $37^{\circ} \mathrm{C}$ for $24 \mathrm{~h}$ and observed for zones of inhibition.

\subsection{Determination of synergistic activity of plant extracts by agar dilution method}

The synergistic activity of plant extracts showing considerable antibacterial activity was evaluated by the agar dilution method. In this method, equal volumes of different plant extracts were mixed thoroughly in a bioassay tube. Similar to the above method, $20 \mathrm{~mL}$ of sterile and molten NA butt was cooled to around $40^{\circ} \mathrm{C}$, seeded with $0.2 \mathrm{~mL}$ of test cultures $\left(0.120 . \mathrm{D}_{540 \mathrm{~nm}}\right)$ and $0.2 \mathrm{~mL}$ TTC, and poured into sterile petri plates. Using a sterile cork borer, wells were punched in each plate after solidification of the medium and $50 \mu \mathrm{L}$ of plant mixture was added to the wells. The plates were incubated at $37^{\circ} \mathrm{C}$ for $24 \mathrm{~h}$ to observe for enhancement of zones of inhibition of the mixture of plant extracts as compared to individual extracts [27].

\section{Results and discussion}

\subsection{Antibiotic resistance profile of test isolates}

Table 3 represents the antibiotic resistance profile of the test isolates used in our study. Given the widespread cases of antibiotic resistance globally, most of the isolates collected in our study were candidly expected to be MDR (i.e., resistant to 3 or more antibiotics). The presumed observations clearly showed 14 out of 16 test isolates to be MDR. The other 2 isolates i.e. M-160 and M-109 were not MDR strains; however, they showed intermediate resistance to 11 and 17 out of the 33 antibiotics respectively.

Also, among the 16 isolates, 7 isolates (M-01, M-04, M-40, M-126, M-14, M-33, M-141) showed ESBL production, 4 isolates (M-125, M-09, M-10, M-139) showed both ESBL and carbapenemase production whereas 2 S. aureus isolates (132 and 109) showed ESBL production and resistance to Streptogramins (Quinupristin-dalfopristin).

Research undertaken by the World Health Organisation (WHO) suggests the highest levels of antimicrobial resistance and infection by $\beta$-Lactamase producers (above 50\%) in densely populated countries like India and China. This was mainly attributed to the poor quality of antibiotics and its unsupervised use in most of the regions in these countries [28]. In 2014, WHO reported that over 50\% population of pathogens like E. coli, K. pneumoniae, S. aureus, and $P$. aeruginosa were evolved as MDR and $\beta$-Lactamase producer [11]. Several independent research carried out recently have consistently and perniciously shown a rise in these numbers [29-33]. In a recent study, over $60 \%$ E. coli strains isolated from horse riding centres in Poland were ESBL producers [34]. In another study, carried out in Ethiopia, over 94.5\% gram negative clinical samples collected during a cross sectional study between December 2017 to June 2018 were MDR strains. They further reported $67 \%$ and $2 \%$ isolates to be producers of ESBL and carbapenemase, respectively. Moreover, more than 70\% strains isolated from ICUs were either MDR or ESBL and/or carbapenemase producers [35]. 
Table 3 Antibiotic resistance profile of test pathogens

\begin{tabular}{|c|c|c|c|c|c|}
\hline \multirow{2}{*}{$\begin{array}{l}\text { Reference } \\
\text { code }\end{array}$} & \multirow{2}{*}{ Name of organism } & \multicolumn{3}{|l|}{ Antibiotic resistance profile } & \multirow{2}{*}{$\begin{array}{l}\beta \text {-Lactamase } \\
\text { enzyme produced }\end{array}$} \\
\hline & & Sensitive & Intermediate & Resistant & \\
\hline M-01 & Escherichia coli & $\begin{array}{l}\text { Ac, Pt, Cu, Ci, Cs, Cpm, I, Etp, } \\
\mathrm{Mr}, \mathrm{Ak}, \mathrm{G}, \mathrm{Ti}, \mathrm{Nf}, \mathrm{Cl}\end{array}$ & $\begin{array}{l}\text { Tc, Ca, Le, Mi, Ao, Ban, E, Lz, Dap, Te, Va, T, Ox, } \\
\text { Cd, R }\end{array}$ & As, $\mathrm{Na}, \mathrm{Cf}, \mathrm{Tr}$ & ESBL \\
\hline $\mathrm{M}-125$ & Klebsiella pneuтопіа & $\mathrm{Cl}$ & $\begin{array}{l}\text { Tc, Ca, Le, Mi, Etp, Ao, Ban, E, Lz, Dap, Te, Va, T, } \\
\text { Ox, Cd, R, Ti }\end{array}$ & $\begin{array}{l}\text { As, Ac, Pt, Cu, Ci, Cs, Cpm, I, Mr, } \\
\text { Ak, G, Na, Cf, Nf, Tr }\end{array}$ & \begin{tabular}{|l|l} 
ESBL and \\
Carbapenemase
\end{tabular} \\
\hline $\mathrm{M}-150$ & Burkholderia cepacia & $\mathrm{Ca}, \mathrm{Mr}$ & $\begin{array}{l}\text { Tc, Cs, As, Ac, Pt, Cu, Ci, Cpm, Etp, I, Ak, G, Na, } \\
\text { Nf, Cl, Ao, Ban, E, Lz, Dap, Te, Va, T, Ox, Cd, R }\end{array}$ & Tc, Cf, Le, Mi, Ti, Tr & \\
\hline M-160 & Enterococcus faecalis & $\begin{array}{l}\text { Ban, G, Cf, Le, E, Lz, Dap, Te, } \\
\text { Va, Ti, Nf }\end{array}$ & $\begin{array}{l}\text { Tc, Ca, Cs, Mr, Mi, Tr, As, Ac, Pt, Cu, Ci, Cpm, Etp, } \\
\text { I, Ak, Na, Cl, Ao, Ox, Cd, R }\end{array}$ & $\mathrm{T}$ & \\
\hline $\mathrm{M}-04$ & Escherichia coli & Cs, Etp, I, Mr, Ak, Ti, Nf, Cl & $\begin{array}{l}\text { Tc, Ca, Le, Mi, Ao, Ban, E, Lz, Dap, Te, Va, T, Ox, } \\
\text { Cd, R }\end{array}$ & $\begin{array}{l}\mathrm{As}, \mathrm{Ac}, \mathrm{Pt}, \mathrm{Cu}, \mathrm{Ci}, \mathrm{Cpm}, \mathrm{G}, \mathrm{Na}, \mathrm{Cf}, \\
\mathrm{Tr}\end{array}$ & ESBL \\
\hline M-09 & Acinetobacter baumannii & $\mathrm{Ti}, \mathrm{Cl}$ & $\begin{array}{l}\mathrm{Ca}, \mathrm{As}, \mathrm{Ac}, \mathrm{Cu}, \mathrm{Etp}, \mathrm{Ak}, \mathrm{Na}, \mathrm{Nf}, \mathrm{Ao}, \mathrm{Ban}, \mathrm{E}, \mathrm{Lz}, \\
\text { Dap, Te, Va, T, Ox, Cd, R }\end{array}$ & $\begin{array}{l}\text { Tc, Pt, Ci, Cs, Cpm, I, Mr, G, Cf, } \\
\text { Le, Mi, Tr }\end{array}$ & \begin{tabular}{|l|l} 
ESBL and \\
Carbapenemase
\end{tabular} \\
\hline $\mathrm{M}-40$ & $\begin{array}{l}\text { Enterobacter cloacae ssp. } \\
\text { Dissolvens }\end{array}$ & $\begin{array}{l}\text { Pt, Cs, Cpm, Etp, I, Mr, Ak, G, } \\
\text { Na, Cf, Ti, Cl, Tr }\end{array}$ & $\begin{array}{l}\text { Tc, Ca, Le, Mi, As, Cu, Ao, Ban, E, Lz, Dap, Te, Va, } \\
\text { T, Ox, Cd, R }\end{array}$ & Ac, $\mathrm{Ci}, \mathrm{Nf}$ & ESBL \\
\hline $\mathrm{M}-126$ & Pseudomonas aeruginosa & $\mathrm{Cl}$ & $\begin{array}{l}\text { Tr, As, Ac, Pt, Cu, Ci, Etp, Na, Nf, Ao, Ban, E, Lz, } \\
\text { Te, Va, T, Ox, Cd, R }\end{array}$ & $\begin{array}{l}\text { Tc, Ca, Cs, Cpm, Dap, I, Mr, Ak, } \\
\text { G, Cf, Le, Mi, Ti }\end{array}$ & ESBL \\
\hline $\mathrm{M}-10$ & Klebsiella pneumonia & $\mathrm{Ak}, \mathrm{G}, \mathrm{Cl}, \mathrm{Tr}$ & $\begin{array}{l}\text { As, Ac, Cu, Ci, Etp, I, Na, Nf, Ban, E, Lz, Te, Va, T, } \\
\text { Ox, Cd, R, Ti }\end{array}$ & $\begin{array}{l}\text { Tc, Pt, Ca, Cs, Cpm, Ao, Dap, } \\
\mathrm{Mr}, \mathrm{Cf}, \mathrm{Le}, \mathrm{Mi}\end{array}$ & $\begin{array}{l}\text { ESBL and } \\
\text { Carbapenemase }\end{array}$ \\
\hline M-139 & Acinetobacter baumannii & $\mathrm{Cl}$ & $\begin{array}{l}\text { Ca, As, Ac, Cu, Etp, Ak, G, Na, Nf, Ao, Ban, E, Lz, } \\
\text { Dap, Te, Va, T, Ox, Cd, R, Ti }\end{array}$ & $\begin{array}{l}\text { Tc, Pt, Ci, Cs, Cpm, I, Mr, G, Cf, } \\
\text { Le, } \mathrm{Mi}, \mathrm{Tr}\end{array}$ & $\begin{array}{l}\text { ESBL and } \\
\text { Carbapenemase }\end{array}$ \\
\hline M-14 & Escherichia coli & $\begin{array}{l}\mathrm{Pt}, \mathrm{Cu}, \mathrm{Ci}, \mathrm{Cs}, \mathrm{Cpm}, \mathrm{Etp}, \mathrm{I}, \mathrm{Mr}, \\
\mathrm{Ak}, \mathrm{Cf}, \mathrm{Ti}, \mathrm{Nf}, \mathrm{Cl}\end{array}$ & $\begin{array}{l}\text { Tc, Ca, Le, Mi, Tr, Ao, Ban, E, Lz, Dap, Te, Va, T, } \\
\text { Ox, Cd, R }\end{array}$ & Ac, As, G, Na, Tr & ESBL \\
\hline M-33 & $\begin{array}{l}\text { Staphylococcus } \\
\text { epidermidis }\end{array}$ & $\mathrm{Cd}, \mathrm{Lz}, \mathrm{Dap}, \mathrm{Te}, \mathrm{Va}, \mathrm{Ti}, \mathrm{Nf}, \mathrm{R}$ & $\begin{array}{l}\text { Tc, Ca, Cs, Mr, Mi, As, Ac, Pt, Cu, Ci, Cpm, Etp, I, } \\
\text { Ak, G, Na, Cl, Ao }\end{array}$ & Ban, Ox, Cf, Le, E, T, Tr & ESBL \\
\hline M-98 & Enterococcus faecium & $\mathrm{Lz}, \mathrm{Te}, \mathrm{Va}, \mathrm{Ti}$ & $\begin{array}{l}\text { Tc, Ca, Cs, Mr, Mi, Tr, As, Ac, Pt, Cu, Ci, Cpm, Etp, } \\
\text { I, Ak, Na, Cl, Ao, Dap, Ox, Cd, R }\end{array}$ & Ban, G, Cf, Le, E, T, Nf & \\
\hline M-132 & Staphylococcus aureus & Lz, Dap, Te, Va, Ti, Nf & $\begin{array}{l}\text { Tc, Ca, Cs, Mr, Mi, As, Ac, Pt, Cu, Ci, Cpm, Etp, I, } \\
\text { Ak, Na, Cl, Ao }\end{array}$ & Ban, Ox, G, Cf, Le, E, Cd, T, R, Tr & $\begin{array}{l}\text { ESBL and Resistant } \\
\text { to Streptogramins }\end{array}$ \\
\hline M-141 & Pseudomonas aeruginosa & Dap, I, Mr, Ak, G, Cf, Le, Cl & $\begin{array}{l}\text { Tr, As, Ac, Pt, Cu, Ci, Cpm, Etp, Na, Nf, Ao, Ban, } \\
\text { E, Lz, Te, Va, T, Ox, Cd, R }\end{array}$ & $\mathrm{Tc}, \mathrm{Ca}, \mathrm{Cs}, \mathrm{Mi}, \mathrm{Ti}$ & ESBL \\
\hline M-109 & Staphylococcus aureus & $\begin{array}{l}\text { Ox, G, Cf, Le, E, Cd, Lz, Dap, } \\
\text { Te, Va, T, Ti, Nf, R, Tr }\end{array}$ & $\begin{array}{l}\text { Tc, Ca, Cs, Mr, Mi, As, Ac, Pt, Cu, Ci, Cpm, Etp, I, } \\
\text { Ak, Na, Cl, Ao }\end{array}$ & Ban & $\begin{array}{l}\text { ESBL and Resistant } \\
\text { to Streptogramins }\end{array}$ \\
\hline
\end{tabular}




\subsection{Preliminary study of methanol and water extracts of plant products on Lab cultures}

Table 4 represents the preliminary antibacterial activity of methanol $(10 \mathrm{mg} / \mathrm{mL})$ and water extracts $(10 \mathrm{mg} / \mathrm{mL})$ of plant products on representative gram positive ( $S$. aureus and $S$. aureus $6538 \mathrm{p}$ ) and gram negative (E. coli) lab cultures. As observed in the table, the undiluted solvent extracts, except for onion, were ineffective against test cultures. The methanol extract of onion showed activity against gram positive cultures only. The undiluted water extracts of clove, garlic, cinnamon and onion showed considerable zones of inhibition against one or more lab cultures. Significant zones of inhibition of plant extracts were observed against lab cultures when the solvent extracts were diluted 1:1 with DMSO. From these observations it was concluded that the viscosity of the concentrated extracts may have prevented the diffusion of extracts in the media, hence resulting in no zones of inhibition. Also, in the current study, garlic and green tea extracts showed antibacterial activity against all three lab cultures (i.e. both gram positive and gram negative).

Table 4 Antibacterial activity of methanol and water extracts of plant products on lab cultures

\begin{tabular}{|c|c|c|c|}
\hline \multirow[t]{2}{*}{ Plant extracts } & \multicolumn{3}{|c|}{ Zone of inhibition (mm) } \\
\hline & S. aureus & S. aureus 6538p & E. coli \\
\hline \multicolumn{4}{|l|}{ Clove } \\
\hline Solvent extract (undiluted) & - & - & - \\
\hline Water extract (undiluted) & 28 & 17 & - \\
\hline Solvent extract (diluted) & 29 & 29 & - \\
\hline Water extract (diluted) & 15 & 16 & - \\
\hline \multicolumn{4}{|l|}{ Garlic } \\
\hline Solvent extract (undiluted) & - & - & - \\
\hline Water extract (undiluted) & 17 & 24 & 17 \\
\hline Solvent extract (diluted) & 15 & 15 & 21 \\
\hline Water extract (diluted) & - & - & - \\
\hline \multicolumn{4}{|l|}{ Cinnamon } \\
\hline Solvent extract (undiluted) & - & - & - \\
\hline Water extract (undiluted) & 20 & 13 & - \\
\hline Solvent extract (diluted) & 19 & 15 & 12 \\
\hline Water extract (diluted) & 16 & 12 & - \\
\hline \multicolumn{4}{|l|}{ Onion } \\
\hline Solvent extract (undiluted) & 13 & 11 & - \\
\hline Water extract (undiluted) & 10 & - & - \\
\hline Solvent extract (diluted) & 9 & - & - \\
\hline Water extract (diluted) & - & - & - \\
\hline \multicolumn{4}{|l|}{ Green tea } \\
\hline Solvent extract (undiluted) & - & - & - \\
\hline Water extract (undiluted) & - & - & - \\
\hline Solvent extract (diluted) & 21 & 23 & 14.5 \\
\hline Water extract (diluted) & 19.5 & 14 & 14 \\
\hline \multicolumn{4}{|l|}{ Indian borage } \\
\hline Solvent extract (undiluted) & - & - & - \\
\hline Water extract (undiluted) & - & - & - \\
\hline Solvent extract (diluted) & 14.5 & - & - \\
\hline Water extract (diluted) & 14 & - & - \\
\hline
\end{tabular}

The broad spectrum antibacterial activity of garlic and green tea is also reported previously by many researchers [3639]. Similar to our findings, Farjana et al. [40] reported antibacterial activity of green tea against S. aureus, but no activity 
against $E$. coli. The bioactive components in medicinal plants work by mechanisms of inhibition of cell wall synthesis, accumulation in bacterial membranes causing energy depletion, increased cell permeability, membrane disruption and change of the structure and function of key cellular constituents. These mechanisms result in mutations, cellular damage and ultimately cellular death. In general, gram positive bacteria are more sensitive to antibacterial agents of natural or synthetic origin as compared to gram negative bacteria. This is due to the complex cell wall structure of the gram negative bacteria that prevent the easy diffusion of molecules inside the cell [41]. In this study, both solvent and water extracts showed significant antibacterial activity. However, water extracts are much more practical, economical as well as acceptable in pharmaceutical applications. Hence further studies were carried out using $5 \mathrm{mg} / \mathrm{mL}$ concentration of water extracts.

\subsection{Qualitative study of methanol and water extracts of plant products on test organisms}

Table 5 represents the qualitative antibacterial activity of water extracts $(5 \mathrm{mg} / \mathrm{mL})$ of plant products on test pathogens. As predicted from the preliminary results on lab cultures, garlic and green tea extracts were expected to give considerable antibacterial activity against test pathogens. This is because the plant extracts are a blend of several bioactive components. These components may act synergistically against pathogens. Moreover, the MDR pathogens are rarely exposed to these agents and hence seldom acquire resistance towards plant extracts [42, 43]. Hence consistent results can be generally expected from plant extracts against drug sensitive as well as resistant pathogens. However, interestingly, the green tea extracts were ineffective on most of the test pathogens used in our study. Instead, Indian borage showed significant zones of inhibition in the range of $11-27 \mathrm{~mm}$ against all test pathogens except two (M-01 and $\mathrm{M}-150$ ). Garlic extracts also showed considerable antibacterial activity with zones of inhibition in the range of 9-21 mm against all test pathogens except P. aeruginosa isolates (M-126 and M-141).

Table 5 Antibacterial activity of water extracts of plant products on test pathogens

\begin{tabular}{|c|c|c|c|c|c|c|c|}
\hline \multirow{2}{*}{$\begin{array}{l}\text { Reference } \\
\text { code }\end{array}$} & \multirow[t]{2}{*}{ Organism } & \multicolumn{6}{|c|}{ Zones of inhibition (mm) } \\
\hline & & Clove & Garlic & Cinnamon & Onion & Green tea & $\begin{array}{l}\text { Indian } \\
\text { borage }\end{array}$ \\
\hline M-01 & Escherichia coli & - & 17 & - & - & - & - \\
\hline M-04 & Escherichia coli & - & 15 & - & - & - & 10 \\
\hline M-09 & $\begin{array}{l}\text { Acinetobacter } \\
\text { baumannii }\end{array}$ & - & 13 & - & - & - & 12 \\
\hline $\mathrm{M}-10$ & $\begin{array}{l}\text { Klebsiella } \\
\text { pneumonia }\end{array}$ & 18 & 11 & - & - & - & 27 \\
\hline $\mathrm{M}-14$ & Escherichia coli & - & 18 & - & - & - & 20 \\
\hline M-33 & $\begin{array}{l}\text { Staphylococcus } \\
\text { epidermidis }\end{array}$ & - & 20 & - & - & - & 20 \\
\hline M-40 & $\begin{array}{l}\text { Enterobacter } \\
\text { cloacae } \\
\text { dissolvens }\end{array}$ & - & 9 & - & - & - & 14 \\
\hline M-98 & $\begin{array}{l}\text { Enterococcus } \\
\text { faecium }\end{array}$ & 16 & 16 & - & 20 & - & 17 \\
\hline M-109 & $\begin{array}{l}\text { Staphylococcus } \\
\text { aureus }\end{array}$ & 17 & 20 & - & - & - & 13 \\
\hline M-125 & $\begin{array}{l}\text { Klebsiella } \\
\text { pneumonia }\end{array}$ & - & 19 & - & - & - & 11 \\
\hline M-126 & $\begin{array}{l}\text { Pseudomonas } \\
\text { aeruginosa }\end{array}$ & - & - & - & - & - & 12 \\
\hline M-132 & $\begin{array}{l}\text { Staphylococcus } \\
\text { aureus }\end{array}$ & 16 & 19 & - & - & 11 & 19 \\
\hline M-139 & $\begin{array}{l}\text { Acinetobacter } \\
\text { baumannii }\end{array}$ & - & 20 & - & - & - & 14.5 \\
\hline M-141 & $\begin{array}{l}\text { Pseudomonas } \\
\text { aeruginosa }\end{array}$ & - & - & - & - & - & 17 \\
\hline M-150 & $\begin{array}{l}\text { Burkholderia } \\
\text { cepacia }\end{array}$ & 11 & 12 & - & - & - & - \\
\hline M-160 & $\begin{array}{l}\text { Enterococcus } \\
\text { faecalis }\end{array}$ & - & 21 & - & 12 & 20 & 15 \\
\hline
\end{tabular}


The antibacterial activity of garlic is attributed mainly to allicin, di allyl thiosulphinic acid or diallyl disulphate [44]. Allicin, particularly acts by targeted inhibition of RNA synthesis and partial inhibition of DNA and protein synthesis [45]. It is also postulated that bioactive components in garlic extract inhibit succinic dehydrogenase by inactivation of thiol group [46]. The presence of carvacrol and camphor as major constituents could contribute to the antibacterial activity of Indian borage [47]. Other components like alpha-terpinene, gamma-terpinene and o-cymene present in low concentrations in Indian borage, may be responsible for its antibacterial activity [48].

A study reported appreciable antibacterial activity of Indian borage on foodborne pathogens namely S. aureus, B. cereus, E. coli and Y. enterocolitica [49]. Moreover, the anti-biofilm efficacy of Indian borage has also been reported against Streptococcus pyogenes isolated from pharyngitis patients [50]. The garlic extract has shown significant reduction of Salmonella in commercial mayonnaise and E. coli in ground meat [51]. Another study reported antibacterial activity of garlic against streptomycin-resistant $S$. aureus and E. coli [52].

\subsection{Determination of synergistic activity of garlic and Indian borage extracts}

Water extract of Indian borage and garlic, when used together, did not show enhancement of zones of inhibition compared to their individual zones observed in Table 5.

Previous studies have reported synergistic activity of Camellia sinensis and Juglans regia on MDR pathogens [53]. The synergistic activity of garlic and antibiotics has also been reported in another study [54]. To the best of our knowledge, the synergistic activity of Indian borage with other plants or antibiotics has not been reported.

\section{Conclusion}

The increasing antibiotic resistance among pathogens towards commonly used antibiotics is increasingly creating a challenge for medical practitioners as well as patients. Today, any case of infection requires closed monitoring since the fear of existing antimicrobials becoming ineffective is quite possible in near future. Our study clearly demonstrates the extent of spread of MDR pathogens. In order to cope with this scenario several published studies have reported the use of rare or less common plant sources and plant products as an alternative to antibiotics. However, it will definitely be more feasible and economical to use common plants as sources of antibiotics, as attempted in the current study. The preliminary studies clearly show the efficacy of garlic as well as Indian borage against ESBL as well as carbapenamase producers. Further studies on this subject with respect to safety and pharmacokinetics, may lead the way towards hopeful outcome against the battle of antibiotic resistance.

\section{Compliance with ethical standards}

\section{Acknowledgments}

The authors would like to thank Saifee Hospital for providing clinical isolates and NM Medical diagnostic center for disposing the clinical waste.

\section{Disclosure of conflict of interest}

The authors declare that they have no conflict of interest.

\section{References}

[1] Zilberberg MD and Shorr AF. (2010). Understanding cost-effectiveness. Clinical Microbiology and Infection, 16(12), 1707-1712.

[2] Kumarasamy KK, Toleman MA, Walsh TR, Bagaria J, Butt F, Balakrishnan R, Chaudhary U, Doumith M, Giske CG, Irfan S, Krishnan P, Kumar AV, Maharjan S, Mushtaq S, Noorie T, Paterson DL, Pearson A, Perry C, Pike R, Rao B, Ray U, Sarma JB, Sharma M, Sheridan E, Thirunarayan MA, Turton J, Upadhyay S, Warner M, Welfare W, Livermore DM and Woodford N. (2010). Emergence of a new antibiotic resistance mechanism in India, Pakistan, and the UK: a molecular, biological, and epidemiological study. The Lancet Infectious Diseases, 10(9), 597-602.

[3] Bush K. (2018). Past and Present Perspectives on $\beta$-Lactamases. Antimicrobial agents and Chemotherapy, 62, e01076. 
[4] Shakya P, Shrestha D, Maharjan E, Sharma VK and Paudyal R. (2017). ESBL production among E. coli and Klebsiella spp. causing urinary tract infection: a hospital based study. Open Microbiology Journal, 28(11), 23-30.

[5] Yong D, Toleman MA, Giske CG, Cho HS, Sundman K, Lee K and Walsh TR. (2009). Characterization of a new metallo-beta-lactamase gene, bla(NDM-1), and a novel erythromycin esterase gene carried on a unique genetic structure in Klebsiella pneumoniae sequence type 14 from India. Antimicrobial Agents and Chemotherapy, 53(12), 5046-5054.

[6] Rawat D and Nair D. (2010). Extended-spectrum $\beta$-lactamases in gram negative bacteria. Journal of Global Infectious Diseases, 2(3), 263-274.

[7] Queenan AM and Bush K. (2007). Carbapenemases: the versatile beta-lactamases. Clinical Microbiology Reviews, 20(3), 440-458.

[8] Mostafa AA, Al-Askar AA, Almaary KS, Dawoud TM, Sholkamy EN and Bakri MM. (2018). Antimicrobial activity of some plant extracts against bacterial strains causing food poisoning diseases, Saudi Journal of Biological Sciences, 25(2), 361-366.

[9] Cowan MM. (1999). Plant products as antimicrobial agents. Clinical Microbiology Reviews, 12(4), 564-582.

[10] Ionescu MI. (2017). Are herbal products an alternative to antibiotics?, Bacterial Pathogenesis and Antibacterial Control, Sahra, IntechOpen.

[11] Atef NM, Shanab SM, Negm SI and Abbas YA. (2019). Evaluation of antimicrobial activity of some plant extracts against antibiotic susceptible and resistant bacterial strains causing wound infection. Bulletin of National Research Centre, 43, 144.

[12] Mambe FT, Iya JN, Fotso GW, Ashu F, Ngameni B, Ngadjui BT, Beng VP and Kuete V. (2019). Antibacterial and antibiotic modifying potential of crude extracts, fractions, and compounds from Acacia polyacantha Willd. against MDR gram-negative bacteria. Evidence-Based Complementary and Alternative Medicine, Article ID 7507549, 13.

[13] Houghton PJ. (1995). The role of plants in traditional medicine and current therapy. Journal of Alternative and Complementary Medicine, 1(2), 131-143.

[14] Dubey NK, Kumar R and Tripathi P. (2004). Global promotion of herbal medicines: India's opportunity. Current Science, 86(1), 37-41.

[15] Sofowora A, Ogunbodede E and Onayade A. (2013). The role and place of medicinal plants in the strategies for disease prevention. African Journal Of Traditional, Complementary, and Alternative Medicines, 10(5), $210-229$.

[16] Yuan H, Ma Q, Ye L and Piao G. (2016). The traditional medicine and modern medicine from natural products. Molecules, 21(5), 559.

[17] Venugopal A, Dasani S and Rai S. (2009). Antibacterial effect of herbs and spices extract on Escherichia coli. Electronic Journal of Biology, 52(2), 40-44.

[18] Parle M and Khanna D. (2011). Clove: A champion spice. International Journal of Research in Ayurveda and Pharmacy, 2(1), 47-54.

[19] Verma SK, Garg AK, Singh M, Panwar N, Meena M and Singh C. Evaluation of analgesic activity of Sygyzium aromaticum w.s.r. to painful tooth. World Journal of Pharmaceutical Research, 7(5), 827-834.

[20] Omar SH and Al-Wabel NA. (2010). Organosulfur compounds and possible mechanism of garlic in cancer. Saudi Pharmaceutical Journal, 18(1), 51-58.

[21] Salehi B, Ata A, Kumar NVA, Sharopov F, Ramírez-Alarcón K, Ruiz-Ortega A, Ayatollahi AS, Fokou TPV, Kobarfard F, Zakaria AZ, Iriti M, Taheri Y, Martorell M, Sureda A, Setzer WN, Durazzo A, Lucarini M, Santini A, Capasso R, Ostrander EA, Rahman A, Choudhary MI, Cho WC and Rad SJ. (2019). Antidiabetic potential of medicinal plants and their active components. Biomolecules, 9(10), 551.

[22] Nicastro HL, Ross SA and Milner JA. (2015). Garlic and onions: their cancer prevention properties. Cancer prevention research (Philadelphia, Pa.), 8(3), 181-189.

[23] Sarah FC and Lambert JD. (2011). The role of antioxidant versus pro-oxidant effects of green tea polyphenols in cancer prevention. Molecular Nutrition \& Food Research, 55(6), 844-854.

[24] Gupta SK and Negi PS. (2016). Antibacterial activity of Indian borage (Plectranthus amboinicus Benth) leaf extracts in food systems and against natural microflora in chicken meat." Food Technology and Biotechnology, 54(1), 90-102. 
[25] Joe MM, Jayachitra J and Vijayapriya M. (2009). Antimicrobial activity of some common spices against certain human pathogens. Journal of Medicinal Plants Research, 3(11), 1134-1136.

[26] Clinical and Laboratory Standards Institute. (2011). Performance standards for antimicrobial disc susceptibility tests, Vol. 31 No. 1. document M100-S21.

[27] Clinical and Laboratory Standards Institute. (2006). Methods for dilution antimicrobial susceptibility tests for bacteria that grow aerobically-seventh edition: approved standard M07-A7. CLSI, Wayne, PA.

[28] Hu YJ, Ogyu A, Cowling BJ, Fukuda K and Pang HH. (2019). Available evidence of antibiotic resistance from extended-spectrum $\beta$-lactamase-producing Enterobacteriaceae in paediatric patients in 20 countries: a systematic review and meta-analysis. Bulletin of World Health Organisation, 97, 486-501.

[29] Legese MH, Weldearegay GM and Asrat D. (2017). Extended-spectrum beta-lactamase- and carbapenemaseproducing Enterobacteriaceae among Ethiopian children. Infection and Drug Resistance, 10, 27-34.

[30] Madec JY, Haenni M, Nordmann P and Poirel L. (2017). Extended-spectrum $\beta$-lactamase/AmpC- and carbapenemase-producing Enterobacteriaceae in animals: a threat for humans? Clinical Microbiology and Infection, 23(11), 826-833.

[31] Bhaskar BH, Mulki SS, Joshi S, Adhikary R and Venkatesh BM. (2019). Molecular characterization of extended spectrum $\beta$-lactamase and carbapenemase producing Klebsiella pneumoniae from a tertiary care hospital. Indian Journal Of Critical Care Medicine, 23(2), 61-66.

[32] Olalekan A, Onwugamba F, Iwalokun B, Mellmann A, Becker K and Schaumburg F. (2020). High proportion of carbapenemase-producing Escherichia coli and Klebsiella pneumoniae among extended-spectrum $\beta$-lactamaseproducers in Nigerian hospitals. Journal of Global Antimicrobial Resistance, 21, 8-12.

[33] Devi U, Bora R, Das JK and Mahanta J. (2018). Extended-spectrum $\beta$-lactamase \& carbapenemase-producing gram-negative bacilli in neonates from a tertiary care centre in Dibrugarh, Assam, India. Indian Journal of Medical Research, 147, 110-114.

[34] Wolny-Koładka K and Lenart-Boroń A. (2018). Antimicrobial resistance and the presence of extended-spectrum beta-lactamase genes in Escherichia coli isolated from the environment of horse riding centers. Environmental Science and Pollution Research International, 25(22), 21789-21800.

[35] Beyene D, Bitew A, Fantew S, Mihret A and Evans M. Multidrug-resistant profile and prevalence of extended spectrum $\beta$-lactamase and carbapenemase production in fermentative Gram-negative bacilli recovered from patients and specimens referred to National Reference Laboratory, Addis Ababa, Ethiopia. PLOS ONE, 14(9), e0222911.

[36] Arora DS and Kaur J. (1999). Antimicrobial activity of spices. International Journal of Antimicrobial agents, 12(3), 257-62.

[37] Elnima EI, Ahmed SA, Mekkawi AG and Mossa JS. (1983). The antimicrobial activity of garlic and onion extracts. Pharmazie, 38(11), 747-748.

[38] Maharajan D, Singh A, Lekhak B, Basnyat S and Gautam LS. (2011). Study on antibacterial activity of common spices. Nepal Journal of Science and Technology, 12, 312-317.

[39] Khan UA, Rahman H, Niaz Z, Qasim M, Khan JT and Rehman B. (2013). Antibacterial activity of some medicinal plants against selected human pathogenic bacteria. European Journal of Microbiology and Immunology, 3(4), $272-274$.

[40] Farjana A, Zerin N and Kabir MS. (2014). Antimicrobial activity of medicinal plant leaf extracts against pathogenic bacteria. Asian Pacific Journal of Tropical Disease, 4(2), S920-S923.

[41] Shihabudeen MS, Priscilla HD and Kavitha T. (2010). Antimicrobial activity phytochemical analysis of selected Indian folk medicinal plants. International Journal of Pharma Sciences and Research, 1(10), 430-434.

[42] Cheesman MJ, Ilanko A, Blonk B and Cock IE. (2017). Developing new antimicrobial therapies: are synergistic combinations of plant extracts/compounds with conventional antibiotics the solution? Pharmacognosy reviews, 11(22), 57-72.

[43] Subramani R, Narayanasamy M and Feussner KD. (2017). Plant-derived antimicrobials to fight against multidrug-resistant human pathogens. 3 Biotech,7(3), 172. 
[44] Mikaili P, Maadirad S, Moloudizargari M, Aghajanshakeri S and Sarahroodi S. (2013). Therapeutic uses and pharmacological properties of garlic, shallot, and their biologically active compounds. Iranian Journal of Basic Medical Sciences, 16(10), 1031-1048.

[45] Feldberg RS, Chang SC, Kotik AN, Nadler M, Neuwirth Z, Sundstrom DC and Thompson NH. (1988). In vitro mechanism of inhibition of bacterial cell growth by allicin. Antimicrobial agents and chemotherapy, 32(12), 1763-1768.

[46] Borlinghaus J, Albrecht F, Gruhlke MC, Nwachukwu ID and Slusarenko AJ. (2014). Allicin: chemistry and biological properties. Molecules, 19(8), 12591-12618.

[47] Tajkarimi MM, Ibrahim SA and Cliver DO. (2010). Antimicrobial of herb and spice compounds in food. Food Control, 21(9), 1199-1218.

[48] Arumugam G, Swamy MK and Sinniah UR. (2016) Plectranthus amboinicus (Lour.) Spreng: botanical, phytochemical, pharmacological and nutritional significance. Molecules, 21(4), 369.

[49] Bhatt P and Negi P. (2012). Antioxidant and antibacterial activities in the leaf extracts of Indian borage (Plectranthus amboinicus). Food and Nutrition Sciences, 3(2), 146-152.

[50] Manimekalai K, Srinivasan P, Dineshbabu J, Guna G, Teepica P and Darsini D. (2016). Anti-biofilm efficacy of Plectranthus amboinicus against Streptococcus pyogenes isolated from pharyngitis patients. Asian Journal of Pharmaceutical and Clinical Research, 9(4), 348-354.

[51] Negi PS. (2012). Plant extracts for the control of bacterial growth: Efficacy, stability and safety issues for food application. International Journal of Food Microbiology, 156, 7-17.

[52] Palaksha MN, Ahmed M and Das S. (2010). Antibacterial activity of garlic extract on streptomycin-resistant Staphylococcus aureus and Escherichia coli solely and in synergism with streptomycin. Journal of Natural Science, Biology, and Medicine, 1(1), 12-15.

[53] Farooqui A, Khan A, Borghetto I, Kazmi SU, Rubino S and Paglietti B. (2015). Synergistic antimicrobial activity of Camellia sinensis and Juglans regia against multidrug-resistant bacteria. PLoS One, 10(2), e0118431.

[54] Betoni JEC, Mantovani RP, Barbosa LN, Di Stasi LC and Fernandes Jr. A. (2006). Synergism between plant extract and antimicrobial drugs used on Staphylococcus aureus diseases. Memórias do Instituto Oswaldo Cruz, 101(4), $387-390$

\section{How to cite this article}

Patade SV, Philip VV, Amin HM, Mukherjee D, Khan AN, Nair SS, George J, Pandey AS, Mundra PS and K Aruna. (2020). Antibacterial potential of plant extracts on ESBL and Carbapenemase producing pathogens. GSC Biological and Pharmaceutical Sciences, 10(3), 173-183. 